Gut, 1982, 23, 951-956

\title{
Effect of urogastrone on gastric secretion and serum gastrin concentration in patients with duodenal ulceration
}

\author{
C G KOFFMAN, ${ }^{*}$ J B ELDER, P C GANGULI, H GREGORY, and C G GEARY
}

From the University Departments of Surgery and Clinical Haematology, Royal Infirmary, Manchester, and Research Division, ICI Laboratories, Alderley Park, Cheshire

SUMmARY A one-hour infusion of $0.25 \mu \mathrm{g} / \mathrm{kg}$ urogastrone administered to seven patients with duodenal ulceration resulted in significant reduction of basal acid secretion $(\mathrm{p}<0.05)$ but was without significant effect on basal pepsin and intrinsic factor secretion or on serum gastrin concentration. In another group of five patients with duodenal ulceration a one-hour infusion of urogastrone was given on five successive days. On day 1 and 5 urogastrone was administered after establishing a plateau response to intravenous pentagastrin $1.2 \mu \mathrm{g} / \mathrm{kg} / \mathrm{h}$. A mean reduction of $65 \%$ in acid output during the urogastrone infusion was seen on day 1 and this was maintained during the next hour. On day 5 the pentagastrin-stimulated acid output was less than on day 1 and a further significant decrease was noted after urogastrone. Pepsin and intrinsic factor output were also significantly inhibited. There was no change in fasting serum gastrin or urogastrone concentration.

Urogastrone has recently been extracted from human material and, although two pure polypeptides were obtained, these were shown to be the same, apart from one additional amino acid. ${ }^{1}$ Studies in humans have been carried out using mixture of the 52 and 53 amino acid residue peptides which have the same biological actions. Studies in normal volunteers ${ }^{2}$ showed that urogastrone $(0.25$ $\mu \mathrm{g} / \mathrm{kg} / \mathrm{h}$ intravenously) inhibited secretagoguestimulated acid secretion with no effect on serum gastrin concentration. In patients with ZollingerEllison syndrome ${ }^{3}$ there was marked inhibition of acid secretion and a rise in serum gastrin concentration. In addition, patients with ZollingerEllison syndrome experienced pain relief during the urogastrone infusion and for up to 24 hours afterwards.

As urogastrone has been found to be virtually free from unwanted side-effects in these human studies and in extensive animal trials over many years, it is possible that it may have a role in the treatment of peptic ulceration. It was therefore considered important to evaluate its effect on gastric secretion

\footnotetext{
* Address for correspondence: C. G. Koffman, Leighton Hospital, Middlewich Road, Crewe CW1 4QJ.

Received for publication 26 February 1982
}

and serum gastrin concentration in patients with active duodenal ulceration both in the basal and pentagastrin-stimulated state. We have also investigated the possibility of a cumulative effect of repeated urogastrone infusions.

\section{Methods}

\section{PATIENTS}

Twelve male patients with chronic duodenal ulcer took part in this study and informed consent was obtained in each case. The diagnosis was confirmed in each patient both by barium meal and duodenoscopy which was always performed within seven days of the start of the study. Only patients with no history of physical signs of disease of any other major system were included, and no patient had previously undergone gastric surgery. In addition, no patients received $\mathrm{H}_{2}$-receptor antagonists within two weeks of the study. Another five patients with duodenal ulceration underwent pentagastrin infusion over a three-hour period in order to act as controls.

BASAL STUDY

In seven of the 12 patients, mean age 41 years (range $28-49$ years) and mean weight $76 \mathrm{~kg}$ (range $52-93 \mathrm{~kg}$ ), 
the effect of urogastrone $(0.25 \mu \mathrm{g} / \mathrm{kg} / \mathrm{h})$ on basal gastric secretion was studied.

All subjects had normal values for blood count, ESR, platelets, electrolytes, and liver function tests.

After a 12-hour fast a nasogastric tube was passed into the stomach and the fasting residue removed. The gastric secretions were continuously aspirated and the juice collected at 15 -minute intervals for three hours.

At the start of the test two indwelling plastic cannulae were inserted into suitable forearm veins of one arm and saline $154 \mathrm{mmol} / \mathrm{l}$ infused. The drip sets were screened from the subject so that he was not aware of changes in the infusion fluid. During the second hour of the test urogastrone $(0.25$ $\mu \mathrm{g} / \mathrm{kg} / \mathrm{h}$ ) was infused for 60 minutes but during the first and third hours only $\mathrm{NaCl}$ was administered. A third cannula was inserted into the other arm and samples of venous blood were taken for serum gastrin and urogastrone measurements at 15 -minute intervals throughout the period of the study. This cannula was kept patent by filling it with $1 \mathrm{ml}$ heparinised saline solution (10 units per $\mathrm{ml}$ ). Throughout the study all the infusions were made using saline $154 \mathrm{mmol} / \mathrm{l}$ at a constant rate of $25 \mathrm{ml} / \mathrm{h}$.

\section{FIVE DAY STUDY}

Five of the 12 patients, mean age 28 years (range 20-42 years) and mean weight $66 \mathrm{~kg}$ (range 53-78 $\mathrm{kg}$ ), participated in the second part of the study in which a one-hour infusion of urogastrone was given each day for five consecutive days. On day 1 and 5, the initial protocol for the test was as stated above except that the first intravenous saline infusion line was used for the administration of pentagastrin at maximal dose $(1.2 \mu \mathrm{g} / \mathrm{kg} / \mathrm{h})$ which produced a gastric acid secretory plateau for three hours. During the second hour urogastrone $(0.25 \mu \mathrm{g} / \mathrm{kg} / \mathrm{h})$ instead of saline was infused through the second intravenous line. Gastric secretions were aspirated at 15-minute intervals throughout the three hours of the test.

On day 2, 3 and 4, only the one-hour intravenous infusion of urogastrone was given, each morning, to the fasting patient.

Another five male patients of mean age 32 years (range 21-51 years), and mean weight $52 \mathrm{~kg}$ (range $55-83 \mathrm{~kg}$ ), with active duodenal ulceration, underwent a three-hour pentagastrin and saline infusion in order to act as controls for the second part of the study. The protocol was identical with that already described except that no urogastrone was given during the second hour.

CLINICAL AND LABORATORY MEASUREMENTS In the first part of the study, measurements of pulse, blood pressure, and temperature were recorded at 15-minute intervals and subjective comments on any discomfort noted by each patient before, during, and after urogastrone infusion were noted. Further haematological studies of blood count, ESR, platelets, electrolytes, and liver function tests were performed immediately after the study and one week later.

In the second part of the study 24-hour urine samples for urogastrone assay were collected on the day preceding the test and throughout each of the five test days. Blood samples were taken for the full range of haematological and biochemical investigations listed above, before and after the five-day period and also on day 3 .

In all cases 15-minute aliquots of gastric juice were titrated with $0 \cdot 1 \mathrm{~N} \mathrm{NaOH}$ to the endpoint of phenol red ( $\mathrm{pH}$ 6.8-8.4) and both acid concentration and output calculated. Samples were assayed for pepsin concentration using a modification of the Anson and Mirsky method on an autoanalyser ${ }^{4}$ and pepsin output calculated. Estimations of intrinsic factor concentration were also made using the radiocobalt method of Ardeman and Chanarin. ${ }^{5}$ Serum samples were stored at $-20^{\circ}$ for up to four weeks and assayed for gastrin and urogastrone concentration by radioimmunoassay methods. ${ }^{6}$

Statistical analysis was performed using the Wilcoxon matched-pairs signed-ranks test for nonparametric basal data and Student's $t$ test for paired data in the pentagastrin study.

\section{Results}

\section{BASAL STUDY}

Basal acid output, concentration, and volume are not normally distributed and therefore in Fig. 1 all individual results have been shown together with the median for each 15-minute collection period. Figure 1 shows the changes in the median basal acid output in response to a one-hour urogastrone infusion. The final 15-minute collection period pre-urogastrone has been taken as the most representative sample of basal acid output and subsequent periods have been compared with this. There was significant inhibition of output during the final 15-minute period of the urogastrone infusion and in the first period after urogastrone was withdrawn $(p<0.05)$.

Acid concentration was significantly reduced $(p<0.05)$ during the final 45 minutes of the urogastrone infusion and the inhibition was maintained for a further 45 minutes after urogastrone withdrawal.

There was no significant change in gastric juice volume, pepsin output, intrinsic factor output, or 
Fig. 1 Effect of urogastrone on median basal acid output. Each point represents a single patient.

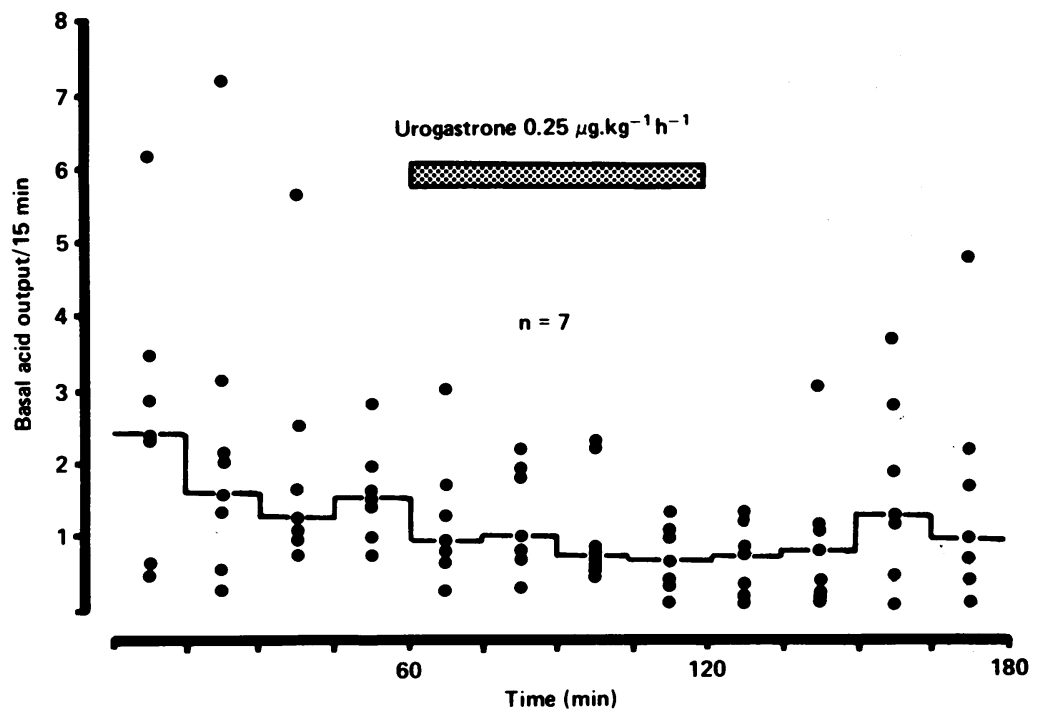

serum gastrin concentration in response to urogastrone. No clinical, biochemical, or haematological side-effects were observed.

\section{FIVE DAY STUDY}

As this part of the study involved a continuous three-hour pentagastrin infusion and acid output is known to 'fade' over this period of time, it was thought important to study the magnitude of this 'fade' and whether it affected pepsin output.
Therefore the effect of a continuous three-hour control infusion of pentagastrin and saline on acid and pepsin output was studied in the five controls with duodenal ulcer and is illustrated in Fig. 2. There was no reduction in pepsin output during the pentagastrin infusion but there was a significant $(p<0.01)$ fall-off in acid output during the threehour period of the study.

The effect of urogastrone on pentagastrinstimulated acid output is shown in Fig. 3. On day 1,
Fig. 2 Effect or three-hour infusion of pentagastrin on acid and pepsin output (mean $\pm S E M)$.

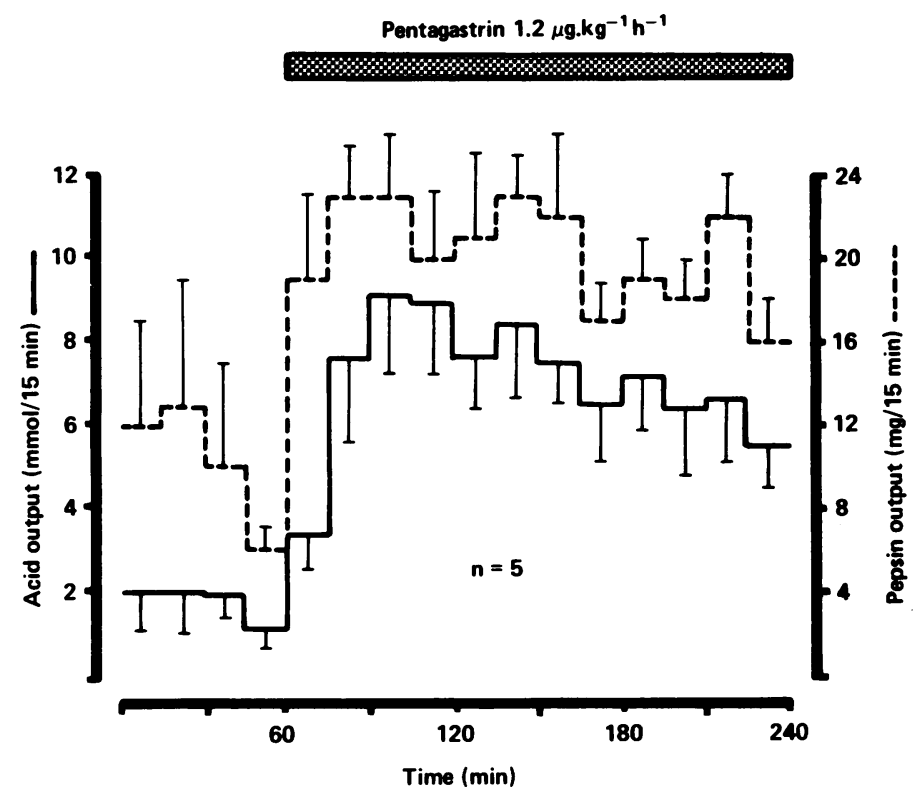


Fig. 3 Effect of urogastrone on pentagastrin-stimulated acid output (mean $\pm S E M)$.

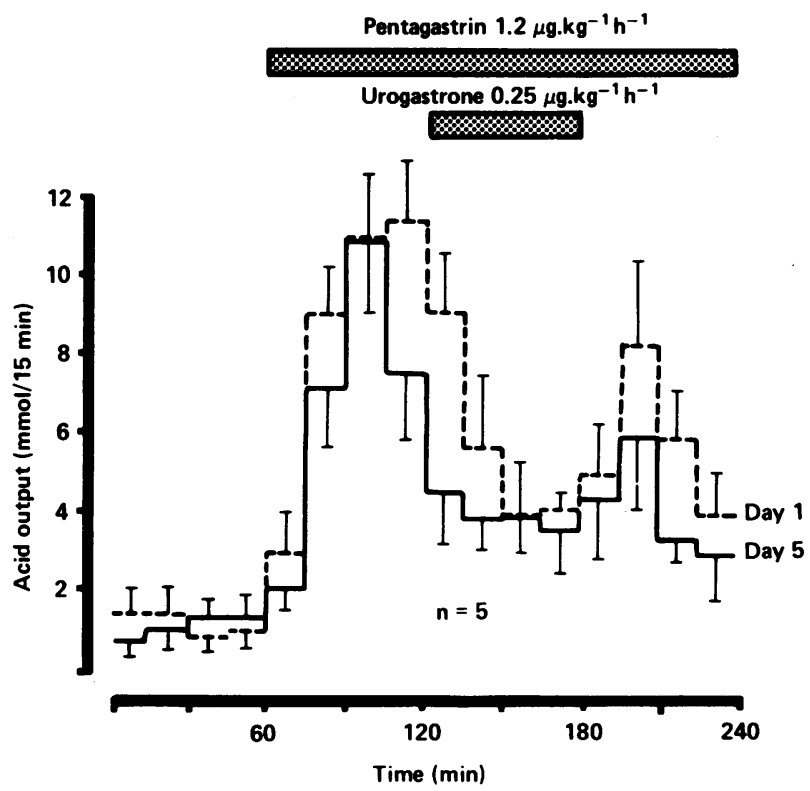

after maximal stimulation with pentagastrin, urogastrone produced a significant reduction of $65 \%$ in mean acid output during the last half-hour of the infusion $(p<0 \cdot 01)$. In the final hour, after withdrawal of urogastrone, a small increase in acid output was observed but this was followed by a further fall. The mean total output during each hourly period on day 5 was less than on day 1 and this reached statistical significance during the first and third hours of the pentagastrin infusion $(\mathrm{p}<0.05)$.

The reduction in acid output in response to urogastrone was largely a result of a decrease in the volume of gastric secretions (Fig. 4). There was a significant decrease of $51 \%(p<0.05)$ in volume during the last half-hour of the urogastrone infusion. Acid concentration was reduced by $20 \%$ during this period but this reduction was not statistically significant (Fig. 4).

Pentagastrin-stimulated pepsin output was significantly reduced by $65 \%(\mathrm{p}<0.01)$ during the last half-hour of urogastrone infusion on both day 1 and day 5. There was no change in pepsin concentration during urogastrone infusion and therefore changes in pepsin output appear to depend upon changes in the volume of gastric output from day 1 to day 5 .

Pentagastrin-stimulated intrinsic factor output was reduced significantly by $77 \%(\mathrm{p}<0.05)$ during the pentagastrin infusion on day 1 and, although output then increased after withdrawal of urogastrone, there was still a $58 \%$ reduction in the final hour (Fig. 5). The results on day 5 were similar in that there was a $68 \%$ inhibition during urogastrone infusion and a $66 \%$ inhibition in the final hour. This inhibition was achieved both by a reduction in volume of secretion but also by a smaller reduction in intrinsic factor concentration which was $40 \%$ on day 1 and $30 \%$ on day 5 . In this respect intrinsic factor secretion behaved in a similar way to acid secretion. In addition, the mean pentagastrin-stimulated intrinsic factor output was significantly reduced on day 5 compared with day 1 $(p<0.05)$ during the second hour of the study. Again, this was a similar response to that observed for acid output.

There was no change in fasting serum gastrin or serum urogastrone concentration or in 24-hour urinary urogastrone output during the study. No significant biochemical or haematological changes were observed in any of the subjects who were all followed up for at least one month after the urogastrone infusion. No changes in blood pressure, pulse, or temperature were observed during the infusions and although two patients complained of a slight headache during the infusion the symptom had disappeared by the end of the test.

\section{Discussion}

Historically urogastrone was discovered as a consequence of the observed beneficial effect of pregnancy upon peptic ulceration. ${ }^{7}$ It was proposed that extracts of urine used in the early studies 
Fig. 4 Effect of urogastrone on pentagastrin-stimulated acid volume and concentration (mean $\pm S E M)$.

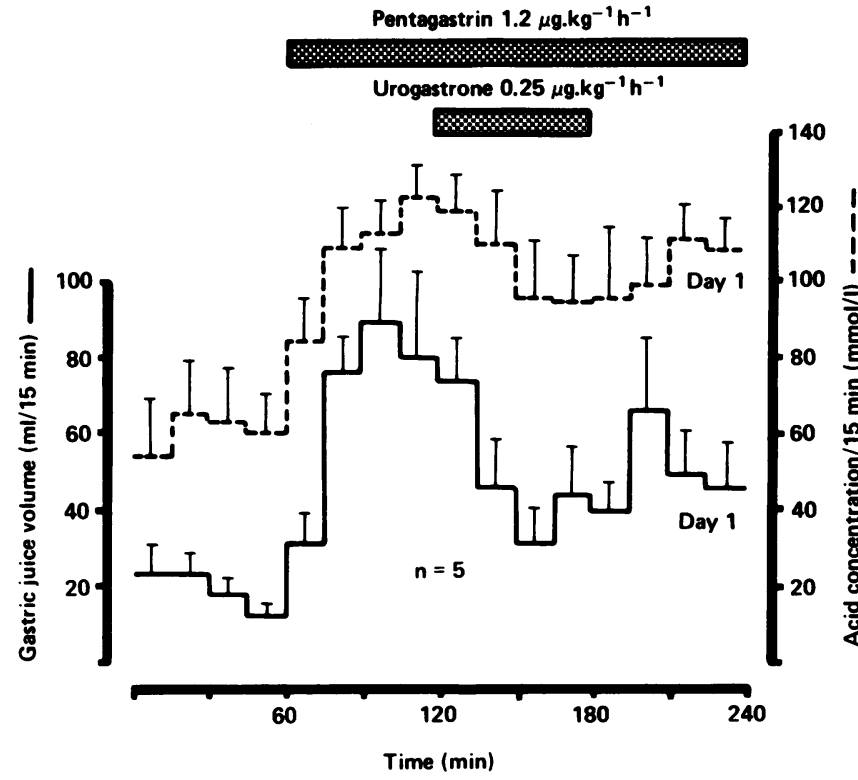

contained two different agents, one of which carried inhibition of gastric acid secretion and a second which promoted ulcer healing. ${ }^{8}$ With the isolation of pure urogastrone it was established that acid inhibitory and mitogenic properties resided in the one molecule and indeed urogastrone appears to be the human equivalent of mouse epidermal growth factor. ${ }^{9}$ This is the first report of the use of urogastrone in patients with active duodenal ulcer disease in the absence of hypergastrinaemia.
In the first part of the study there was a significant reduction in basal acid conentration and, for a shorter period, basal acid output during and after urogastrone infusion. There was no evidence of rebound hypersecretion after urogastrone withdrawal. Pepsin and intrinsic factor output and concentration and serum gastrin concentration remained unchanged. Although the mechanism of action of urogastrone on gastric secretion is not known, this part of the study suggests, along with
Fig. 5 Effect of urogastrone on pentagastrin-stimulated intrinsic factor output (mean $\pm S E M)$.

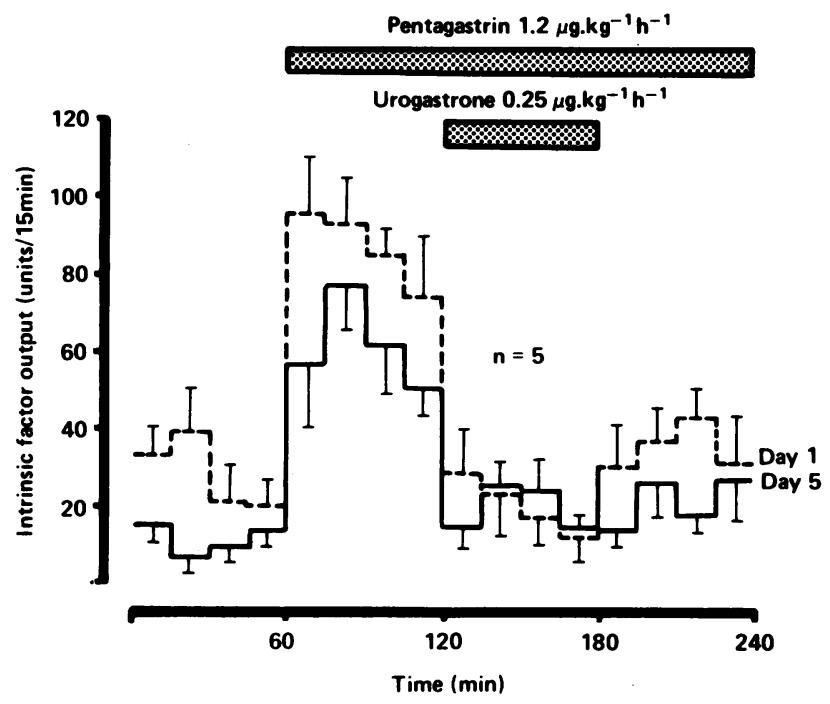


previous findings in normal subjects, ${ }^{2}$ that there is a specific action on hydrogen ion secretion. There is evidence $^{10}$ that urogastrone blocks the effect of pentagastrin on the parietal cell but leaves pepsin output unaffected.

Inhibition of acid secretion in the five-day study $(65 \%)$ was greater than that observed in the Zollinger-Ellison syndrome (54\%) but not so great as that found at the same dosage in normal subjects ${ }^{2}$ $(85 \%)$. Pentagastrone-stimulated acid output was significantly inhibited by urogastrone, whereas acid concentration was not significantly affected and this is at variance with the results of the basal study and the previous findings both in normal and ZollingerEllison patients. It does, however, support findings by Gregory ${ }^{11}$ in gastric fistula dogs and Gerring and Haworth $^{12}$ in Heidenhain pouch dogs stimulated by histamine where acid concentration was scarcely affected; in these instances significant inhibition of acid output was achieved largely by changes in the volume of juice secreted. There was evidence of a cumulative effect of urogastrone during the five day study, in that there was a reduction in the volume of acid secreted in response to pentagastrin on day 5 compared with day 1.

Inhibition of pentagastrin-stimulated pepsin output was a result of a decrease in volume of secretion and there was no significant reduction in pepsin concentration. Intrinsic factor output was inhibited as a result both of significant volume reduction and a smaller, non-significant reduction in concentration. The difference in pepsin and intrinsic factor response between the basal and stimulated states is difficult to explain. Nevertheless, it does appear that the dominant effect is to block the action of gastrin and other agonists at the parietal cell. This is supported by our observations that pentagastrin-stimulated acid and intrinsic factor output behave in a closely similar way in response to urogastrone and this is different from the pepsin response.

The inhibitory action of urogastrone administered intravenously appears to be short-lived and this is in keeping with more recent studies which have shown it to have a short half-life in the dog. ${ }^{13}$ Moreover, because of the steep dose-response curve to urogastrone in man, there is no reason to doubt that increased doses would give greater inhibition. It is now known that larger amounts of immunoreactive urogastrone occur in blood, probably as a high molecular weight precursor of low biological potency, ${ }^{14}$ and this effectively masked attempts to monitor the half-life of the exogenously administered low molecular weight species in the present study.

In conclusion, urogastrone appears to be effective in reducing acid, pepsin, and intrinsic factor output in patients with duodenal ulceration, although the duration of action is short after intravenous administration.

We thank Mrs Ann Tomlin and Dr J Berry for technical assistance in performing the gastric secretory studies and pepsin assays and Miss Gaynor Cheetham for performing the gastrin assays. We are grateful to the technical staff of the Department of Haematology of the Royal Infirmary, Manchester, for performing the intrinsic factor assays and also to the Department of Medical Illustration for their help in preparation of the graphs.

\section{References}

1 Gregory $\mathrm{H}$, Preston BM. The primary structure of human urogastrone. Int J Pept Protein Res 1977; 9: 107-18.

2 Elder JB, Ganguli PC, Gillespie IE, Gerring EL, Gregory $\mathbf{H}$. Effect of urogastrone on gastric secretion and plasma gastrin levels in normal subjects. Gut 1975; 16: 887-93.

3 Elder JB, Ganguli PC, Gillespie IE et al. Effect of urogastrone in Zollinger-Ellison syndrome. Br J Surg 1974; 61 : 916.

4 Anson ML, Mirsky AE. The estimation of pepsin with haemoglobin. J Gen Physiol 1932; 16: 59-63.

5 Ardeman S, Chanarin I. A method for assay of human gastric intrinsic factor and for detection and titration against intrinsic factor. Lancet 1963; 2: 1350-4.

6 Ganguli PC, Hunter WM. Radioimmunoassay of gastrin in human plasma. J Physiol 1972; 220: 499-510.

7 Sandweiss DJ, Saltzstein NC, Farbman AA. Prevention of healing of experimental ulcer in dogs with anterior pituitary-like hormone (Antuitrins). Am J Dig Dis 1938; 5: 24-30.

8 Sandweiss DJ. The immunising effect of the anti-ulcer factor in normal human urine (Anthelone) against the experimental gastrojejunal (peptic) ulcer in dogs. Gastroenterology 1943; 1: 965.

9 Gregory $\mathrm{H}$. Isolation and structure of urogastrone and its relationship to epidermal growth factor. Nature 1975; 257: 325-7.

10 Bower JM. The effect of urogastrone on isolated gastric mucosa. University fo Sheffield: Thesis, 1973.

11 Gregory RA. A new method for the preparation of urogastrone. J Physiol 1955; 129: 528.

12 Gerring EL, Haworth E. The effect of urogastrone on gastric acid secretion in dogs and cats. Rend Gastroenterol 1970; 2: 167.

13 Kiff ES, Elder JB, Gregory H. Half-life of urogastrone in conscious dogs. Gut 1978; 19: A436.

14 Johnson LR, Guthrie PD. Stimulation of rat oxyntic gland mucosal growth by epidermal growth factor. $\mathrm{Am}$ J Physiol 1980; 238: 945-9. 